\title{
PUPILS' TRUST IN TEACHERS AS A KEY PREREQUISITE FOR CHILD SAFETY IN SCHOOL
}

\author{
Zhanna Petrochko \\ Borys Grinchenko Kyiv University, Ukraine \\ Valentyna Kyrychenko \\ Institute of Education Problem, \\ National Academy of Educational Sciences of Ukraine, Ukraine
}

\begin{abstract}
The article deals with the actual issue of safety of a child aged 11-15 years. Its purpose is to define and describe key prerequisite for a child's safety at school ( $5^{\text {th }}-9^{\text {th }}$ grade), based on an analysis of the essence of the safety and results of empirical studies. The novelty of the article is due to the necessity to immediately search for prerequisites, factors, tools and other factors to counteract and overcome bullying in the educational environment.

The article reveals the essence of child safety, as well as indicators that can be used to monitor $5^{\text {th }}-9^{\text {th }}$ grade pupils' safety at school are outlined. Based on survey of teenagers and teachers, as well as correlated relationships, it has been determined that trust in teachers is a prerequisite for a child's safety in the educational environment and manifestation of social behaviour by pupils. Conclusions concerning instruments of establishing trust between pupils and teachers at school and ensuring their safety are formulated.
\end{abstract}

Keywords: safety, bulling, child, teacher, trust.

\section{Introduction}

Guaranteeing the safety of the children in all environments of their livelihoods is a basic condition for meeting their needs, socialization, harmonious development, foundation for the system of ensuring children's rights. In accordance with international standards outlined by the UN Committee on the Rights of the Child, child safety should be interpreted in the broadest sense, namely: protection against all forms of physical and psychological violence, offence or abuse, sexual harassment, peer pressure, bullying, degrading treatment dignity of attitude; such as security against exploitation, drugs, involvement in the worst forms of child labour, armed conflict, etc.

The processes of deformation of values, changes of stereotypes, weakening of the educational function of the family and other factors increase the relevance of the problem of child safety. Today, this problem is becoming more and more urgent due to the rapid spread of such a negative phenomenon as bullying in a 
Petrochko \& Kyrychenko, 2020. Pupils’ Trust in Teachers as a Key Prerequisite for Child Safety in School

child-youth environment, in school in particular. Among the pupils, the most impressionable are teenagers aged 11-15 years.

On January 19, 2019, Law of Ukraine "On Amendments to Certain Legislative Acts of Ukraine on Counteracting Bullying" came into force (Verkhovna Rada of Ukraine, 2018). In particular, the Law of Ukraine "On Education" is supplemented by the clause, which foresees that bullying is the act (act or omission) of participants in the educational process, which consists in psychological, physical, economic, sexual violence, including the use of electronic communications, committed against a minor or junior and (or) such a person in relation to other participants in the educational process, which could have caused or harmed the victim's mental or physical health (Verkhovna Rada of Ukraine, 2017).

However, nowadays, the system of general secondary education in Ukraine does not clearly identify the key prerequisites for child safety at school, as well as indicators which could measure the safety of the environment and the pupils' feelings of safety.

The purpose of the article: based on the analysis of the essence of child safety and the results of empirical research, to determine and describe trust of pupils to teachers as a key prerequisite for the safety of children aged 11-15 years (pupils $5^{\text {th }}-9^{\text {th }}$ grades) in school.

The study used empirical methods such as questionnaires, interviews with teachers, monitoring and methods of descriptive statistics (determining the percentage, arithmetic mean) and the method of correlation analysis. The purpose of the last mentioned method is to establish correlation between the individual factors of influence and the safety of the child.

\section{The Problem of Research and Research Focus}

We define child safety as a state of protection of a person from birth to 18 years from external and internal threats, availability of ways to meet the needs, protection of its rights. A sense of safety is a sense of stability and confidence, ability to generally influence own life and control certain circumstances.

The problem of the children's safety in different environments of their life is the subject of a number of sociological researches and scientific researches. In particular, negative trends in violence against children and young people are evidenced by the global U-Report surveys conducted in 2016-2017 and 2019 among young people aged 13-24 from 36 countries. Thus, according to the 2016-2017 polls, 67\% of respondents confirm that they or their friends have experienced cases of violence, and almost a third of them (29\%) said that they most often suffer from peer abuse (UNICEF, 2016). 
Based on survey in Ukraine in 2019, the number of respondents suffering from peer aggression is significantly higher (62\%). U-reporters say that bullying and abuse are most common at school, meeting (76\%) and social networks (33\%).

It is worth noting that, according to U-Report, $36 \%$ of respondents did not tell anyone about the cases of bullying that happened to them. Almost the same number of respondents (38\%) say this problem to parents, even fewer (27\%) share it with friends (UNICEF, 2019).

According to the 2019 HBSC survey, among children aged 10 to 17 years, $35 \%$ of those polled during the past two months have been abused / humiliated or bullied by others, $37.9 \%$ have been victims of abuse, abuse and humiliation by other adolescents; $21.1 \%$ of respondents admitted that they were "online bullies" and 21.5\% - they were "online victims" (Balakirieva et al., 2019).

The safety of school-age children has been the subject of research by a number of scientists from around the world. In particular, important is research concerning pupils' and teachers' perceptions of school safety. In particular, researchers K. Bosworth, L. Ford, and D. Hernandaz conducted researches of school climate factors that contribute to pupils 'and teachers' perceived security in selected Arizona schools. Yes, it was found that in 9 out of 11 schools, neither teachers nor students expressed extreme safety concerns. When asked what makes school safe, pupils usually informed of components of physical security, although in their opinion, the school climate and staff actions also strengthened feelings of safety. The received results give an opportunity to form a view concerning factors that contribute to the feeling of safety of pupils in and around school (Bosworth, Ford, \& Hernandaz, 2011).

The US Department of Education (USDOE), based on the measurement of school climate in high schools with a focus on safety, interaction and environment, elaborated a three-factor model based on the school climate's dependence on behavioural, academic, medical, social and emotional factors. Researchers C. Bradshaw, T. Waasdorp, K. Debnam and S. Lindstrom Johnson studied the factor structure and measurement invariance of the USDOE model. The research resulted in a model that included 13 subdomains: security (sense of security, billing and aggression, drug use); involvement (teacher relationships, student relationships, educational environment, communication with school, justice and parental involvement); environment (rules and consequences, physical comfort and support, disorder) (Bradshaw, Waasdorp, Debnam, \& Lindstrom Johnson, 2014).

The J. White research focuses on evidence-based instructing for solving school violence and bullying. It is emphasized that: school violence and bullying can have long-term effects on the health and well-being of children and young people; bullying among school-age children and young people can occur both outside the classroom, on the way to and from school, and online. It is emphasized 
Petrochko \& Kyrychenko, 2020. Pupils’ Trust in Teachers as a Key Prerequisite for Child Safety in School

that published evaluations of the results of school programs on violence and bullying conducted in the UK or Ireland are negligible. It is concluded that a good one at one school may not work at another. Emphasis is placed on the necessity to elaborate a systematic, comprehensive approach to preventing and responding to bullying that would comprehensively address all aspects of the problem (White, 2019).

V. Primakova and L. Morska raised the issue of education of pupils in a safe learning environment in secondary schools of Ukraine in general. The authors analysed the current state of the problem; stated that the school's teaching staff should be able to detect, predict and eliminate dangerous situations (Primakova \& Morska, 2019). However, key factors for teacher effectiveness have not been identified.

\section{Methodology of Research}

During the preparation of this article, a secondary analysis of the empirical results of the applied research "Technologies of formation of prosocial behaviour of vulnerable adolescents in general educational institutions" was conducted, which was carried out by employees of the laboratory of physical development and healthy lifestyle of the Institute of Educational Problems of the National Academy of Pedagogical Sciences of Ukraine in 2017-2019 (Fedorchenko et al., 2019).

The questionnaire was chosen as a survey, which can be done either in paper form or through Google Forms, which allows filling in the questionnaire in a convenient and time-consuming way, simplifies the analysis and processing of data with the help of mathematical statistics tools.

In mentioned research, a complex diagnostic methodology was applied from three questionnaires: two questionnaires for teachers "Organizational and technological support for the formation of social behaviour of adolescents" and "Prosocial behaviour through the eyes of teachers" and for pupils "Prosocial behaviour through the eyes of adolescents".

The analysis of the information from the questionnaire blocks "Question about your school”, "Question about your class” and "Question about you” helps to find out the peculiarities of the life of pupils in the educational institution.

The following statements were formulated to analyse the problem of child safety at school:

- no school bullying and humiliation among pupils; emotional atmosphere is favourable (1);

- $\quad$ no physical punishment and humiliation of pupils by teachers; instead the partnership of adults and children is practiced (2); 
- $\quad$ our class is very friendly and students take care of each other's affairs (3);

- $\quad$ in a conflict situation, pupils try to agree and find a solution that is acceptable to all (4);

- $\quad$ pupils are able to abandon proposals for violations of the rights of others, as well as harmful practices to their health (5);

- $\quad$ there are trusted people in the school who can be reached for advice or assistance (6).

For each statement, the students had to define their position: "completely agree”, "partially agree”, "partially disagree” and "completely disagree”. Teachers also defined their position regarding individual statements $(1,2,5,6)$. Thus, the task was also to compare students' and teachers' perceptions of different aspects of child safety at school.

A survey of teachers and pupils was conducted through Google Forms during September-December 2017. The method of obtaining information is to complete a formalized questionnaire with any device.

Poll regions - four regions of Ukraine (Dnipropetrovsk, Cherkasy, Kharkiv, Kyiv regions) and Kyiv city. A total of 1,071 pupils were interviewed (boys 516 people, girls -555 people) from $5-9^{\text {th }}$ grade, aged $11-15$ years from 13 educational institutions located in 9 settlements. Additionally, 136 teachers were surveyed, teaching in these classes.

Sampling was carried out on the basis of experimental establishments, depending on the grade. The selection of experimental educational institutions was carried out based on voluntary participation. At the same time, the requirements that provided representativeness and uniformity of the sample were observed, in particular: regionality, gender and age characteristics of pupils, number of pupils in one classes' parallel. The same number of boys and girls (100-110 people each) participated in survey. The total number of pupils in each parallel was 200-220 people.

According to the length of service of teachers $-77.5 \%$ of respondents have more than 10 years of work and more than half of the respondents - have more than 10 years of experience of classroom management.

Samples of pupils and teachers were compared using the Kramer-Welch (T) statistical criteria. STATISTICA 6.0 was used for correlation analysis and to establish the probability of difference between samples.

As for the location of the educational institution $-64 \%$ of the educational institutions are located in cities and 36\% - in rural areas.

The observance of ethical issues of organizing and conducting the survey were ensured through the preparation of a letter "Informed Consent to Participate in the Research" for management of schools and parents of pupils. The mentioned 
Petrochko \& Kyrychenko, 2020. Pupils' Trust in Teachers as a Key Prerequisite for Child Safety in School

letter contained a description of the conditions and requirements for conducting the survey. Parents provided written permission for participation their children in this survey.

\section{Results of Research}

The survey results "Social behaviour through the eyes of pupils" and "Social behaviour through the eyes of teachers" demonstrated that with the statement concerning the absence of abuse and humiliation among pupils in the school and the domination of a favourable emotional atmosphere, "partially disagree" and "completely disagree" $33.0 \%$ of $5^{\text {th }}$-grade pupils, $28.74 \%$ of $6^{\text {th }}$-grade pupils, $34.79 \%$ of $7^{\text {th }}$-grade pupils, $41.2 \%$ of $8^{\text {th }}$-grade pupils and $43.64 \%$ of $9^{\text {th }}$-grade pupils. At the same time, only $16.1 \%$ of teachers inform of facts of bullying and humiliation, which is two or even three times less than pupils. In our view, this indicates a worrying trend of increasing cases or situations of bullying / danger, encountered by about $1 / 3$ of pupils in $5-7^{\text {th }}$ grades up to almost $1 / 2$ of pupils in 8-9 $9^{\text {th }}$ grades. At the same time, the teachers were not aware about that cases.

$18.77 \%$ of fifth-graders, $19.76 \%$ of sixth-graders, and $13.66 \%$ of seventhgraders, $17.59 \%$ of eighth-graders and $21.91 \%$ of ninth-graders "partially disagree" and "completely disagree" with the statement that there are "no physical punishment and humiliation of pupils by teachers; instead the partnership of adults and children is practiced". It means that with the exception of $7^{\text {th }}$ grade pupils, almost every fifth pupil has seen or experienced bulling at school. At the same time, only 3.7\% of teachers notice physical punishment and humiliation of pupils by teachers. $96.3 \%$ of teachers agree with statement about partnerships between adults and children at school that contradicts the statements of pupils.

The fact that their "class is very friendly and pupils take care of each other's affairs" is "partially disagree" and "completely disagree" over a 1/3 of pupils: $31.44 \%$ of fifth-graders, $32.33 \%$ of sixth-graders, $35.65 \%$ of eighth-graders, $34.09 \%$ of ninth-graders and about a $1 / 3$ (26.77\%) of seventh-graders.

On average, almost every fifth student in a conflict situation does not try to negotiate and find a solution that is acceptable to all: $5^{\text {th }}$ grade $-23.11 \%$; $6^{\text {th }}-$ $22.75 \%$; $7^{\text {th }}-18.47 \%$; $8^{\text {th }}-17.13 \%$; and $9^{\text {th }}-21.82 \%$ ). As follows, the problem at school is the pupils' ability to negotiate and reach compromises (especially among $8^{\text {th }}$-grade pupils) that is a factor of forming friendly, trusting relationships with others.

Practically in all classes $\left(5^{\text {th }}-20.22 \% ; 6^{\text {th }}-21.56 \% ; 8^{\text {th }}-21.86 \%\right.$; $9^{\text {th }}-$ $21.36 \%)$, except $7^{\text {th }}$ (14.84 \%), one in five pupils disagrees with the statement that "pupils are able to refuse suggestions for violating other people's rights or harmful practices for their health". The same position is shared by $14.0 \%$ of teachers. Therefore, appearance of a dominant or aggressive leader in the pupils' team, 
significantly increases the risk of involving pupils in the violation of others' rights. In this case, it is important to understand which person the teenager will seek to be protected.

Thus, majority of adolescent pupils (92.84\%) answer that their "close environment includes adults who they trust and can ask for help”. In general, only $8.16 \%$ of pupils deny this situation.

At the same time, with the statement "there are people in the school who are trusted by all and who can be reached for advice or help" mostly agree the $5^{\text {th }}$ and $7^{\text {th }}$ grade pupils $(90.97 \%$ and $85.87 \%$ respectively). Instead, "slightly disagree" and "completely disagree" more than $1 / 5$ of $8-9^{\text {th }}$ grade pupils $(19.44 \%$ and $22.73 \%$ respectively). That is, from $10-15 \%$ of $5-7^{\text {th }}$ grade pupils to $20-23 \%$ of $8-9^{\text {th }}$ grade pupils do not have teachers among adults in school whom they may trust and seek help in case of danger.

Answers of teachers distributed radically different from pupils: $97.0 \%$ of teachers agree and only $2.2 \%$ deny allegation that there are adult in school who pupils may trust, ask for advice or help. Therefore, teachers are not aware of the identified problem, and do not perceive it as a potential prerequisite for danger for teenager at school.

Table 1 Comparing pupils' and teachers' responses to questionnaires, \%

\begin{tabular}{|c|c|c|c|c|c|c|c|c|}
\hline \multirow{2}{*}{$\begin{array}{c}\text { Answer } \\
\text { options }\end{array}$} & \multicolumn{9}{|c|}{ S 1 } & \multicolumn{2}{c|}{ S 2 } & \multicolumn{2}{c|}{ S 5 } & \multicolumn{2}{c|}{ S 6} \\
\cline { 2 - 10 } & pupils & teachers & pupils & teachers & pupils & teachers & pupils & teachers \\
\hline $\begin{array}{c}\text { Completely } \\
\text { disagree }\end{array}$ & 12.71 & 2.92 & 8.45 & 0.73 & 4.65 & 0 & 4.27 & 0 \\
\hline $\begin{array}{c}\text { Slightly } \\
\text { disagree }\end{array}$ & 23.28 & 13.14 & 9.75 & 2.92 & 15.16 & 13.87 & 11.69 & 2.19 \\
\hline $\begin{array}{c}\text { Slightly } \\
\text { agree }\end{array}$ & 35.81 & 45.99 & 26.74 & 21.90 & 46.79 & 61.31 & 41.56 & 24.82 \\
\hline $\begin{array}{c}\text { Completely } \\
\text { agree }\end{array}$ & 28.2 & 37.23 & 55.06 & 72.99 & 33.4 & 24.09 & 42.49 & 72.99 \\
\hline
\end{tabular}

Source: prepared by authors

$N$ pupils -1071 persons. $N$ teachers -136 persons.

Statement 1. There are no school bullying and humiliation among pupils; emotional atmosphere is favourable.

(Empirical value of Cramer-Welch criteria ('CWC') - 3.0965, critical value of CWC - 1.96, $\mathrm{p}<0.05)$;

Statement 2. There are no physical punishment and humiliation of pupils by teachers; instead the partnership of adults and children is practiced.

(Empirical value of CWC - 3.5669, critical value of CWC - 1.96, $\mathrm{p}<0.05$ );

Statement 5. Pupils are able to abandon proposals for violations of the rights of others, as well as harmful practices to their health.

(Empirical value of CWC - 0.2039, critical value of CWC - 1.96, $\mathrm{p}>0.05$ );

Statement 6 . There are trusted people in the school who can be reached for advice or assistance (Empirical value of CWC -4.9658 , critical value of $\mathrm{CWC}-1.96, \mathrm{p}<0.05$ ). 
Petrochko \& Kyrychenko, 2020. Pupils’ Trust in Teachers as a Key Prerequisite for Child Safety in School

Comparisons of the responses of all grades pupils and teachers to the proposed statements are given in the Table 1.

There was no statistically significant difference between the responses of pupils and teachers in rural and urban educational institutions $(p>0,05)$.

One of the factors that is likely to complicate the identified situation is gender imbalance in the pedagogical environment: almost 92\% (125 persons) of the surveyed teachers are female and only $8 \%$ are male (11 persons). Therefore, the opportunity to seek help from a male teacher is negligible.

Searching for correlation links between respondents' answers showed that pupils' trust to teachers may be treated as the basic prerequisite for children safety and prosocial behaviour at school.

If pupils trust teachers at school, highly probable outcomes are the following:

- there is no abuse and humiliation among pupils, but a favourable emotional atmosphere prevails $(\mathrm{r}=0.9 ; \mathrm{p}<0.05)$;

- pupils jointly solve problems that arise and participate in charitable projects or actions $(\mathrm{r}=0.99 ; \mathrm{p}<0.01)$;

- $\quad$ there are no physical punishments and humiliation of the students by the teachers, instead the partnership of adults and children is practiced $(\mathrm{r}=0.99 ; \mathrm{p}<0.01)$.

\section{Conclusions and suggestions}

Therefore, the results of the survey show that the key aspect of ensuring the safety of the child at school is the trust of the participants in the educational process to each other, and especially the trust of pupils to teachers. Trust appears as a basis for establishing productive contacts and maintain healthy relationships, effective conflict resolution and so on. Failure to consider such a prerequisite for child safety significantly reduces the effectiveness of any action to prevent or eliminate bullying at school or other dangerous situations.

The safety of a child is the basis for harmonious development of an individual, as well as an important condition for a child's prosocial behaviour, his/her desire to act for the good of others and society as a whole.

Feeling child safety affects her relationships with others, including her desire to support the weak, help the needy, intercede for others. Instead, bullying problems, conflicts between different participants in the educational process often become a barrier to develop in pupils such values as tolerance, respect, support, honesty, harmonious communication and coexistence in society. Similar conclusions were made by scientists of the Institute of Problems on Education of the National Academy of Educational Sciences of Ukraine (Kyrychenko, Yezhova, Necherda, Tarasova, \& Demyanchuk, 2016). 
Our findings are in line with the provisions of the UN Committee on the Rights of the Child document "General Comment No. 20 (2016) on the realization of the rights of the child in adolescence". It is noted there that among the factors that contribute to improving the viability and healthy development of teenagers, an important place occupy: strong relations and support of adults, playing key role in their lives; opportunities for participation and decision-making; safe and healthy environment; opportunities to build and maintain friendly relations (Komitet z prav dytyny, 2016).

In our research, we share the findings of researchers that attachment relationships are extremely important for creating a sense of safety for children, since "the person to whom the child is most strongly attached will have the most serious impact on his or her life" (Newfeld \& Mate, 2018, p. 14) and the fact that "deep trusting protects the individual" in difficult life situations (Neubronner, 2015, p. 31). In this regard, great attention has to be paid to all adult trusted by teenagers.

Therefore there are two aspects of safety: objective and subjective. The objective aspect is characterized by the existence or non-existence of real threats. The subjective aspect refers to a person's awareness of the danger and its potential counteraction. As the same time, it is important for adults, in particular teachers, to understand key prerequisites of safety.

In order to avoid the effects of danger, a child of 11-15 years of age, first of all, needs to know which adult to turn to in case of danger, to do it and to know how to do it. Instead, from $10-15 \%$ of $5-7^{\text {th }}$ grade pupils to $20-23 \%$ of $8-9^{\text {th }}$ grade pupils do not have teachers they trust.

This fact is generally confirmed by the survey results U-Report that states that for various reasons, pupils have been hesitant to talk about bulling with teachers, preferring to deal with bullying cases alone or with the help of friends or family (UNICEF, 2019).

In order for the school to become a safe place for the child, teachers should be aware that a key prerequisite for the child's safety is the pupils' trust in the teachers, and be prepared to have a trusting relationship especially with the teenagers.

For these matters, the authors of the article, considering the long experience of teaching and scientific-pedagogical work, recommend:

- develop programs for interactive lessons with teachers about establishing trusting relationships with pupils on the basis of mutual understanding, joint activity, implementation of the principle of child participation in decision-making and society;

- $\quad$ organize regular training of teachers and social pedagogue concerning child protection and mechanisms for responding to risky or threatening 
Petrochko \& Kyrychenko, 2020. Pupils' Trust in Teachers as a Key Prerequisite for Child Safety in School

situations, as well as the specificities of providing assistance to a child when needed;

- develop scenario plans for classes with pupils of different ages to develop skills to avoid potential risks and dangers;

- during professional education of students (future teachers), focus their attention on ability to get involved in modern and interesting for children projects which also treated as socially significant ones;

- develop Code of Safe Educational Environment jointly with children;

- define clear indicators to monitor a child's safety at school, etc.

In addition, we support the suggestion of V. Primakova and L. Morska for wider use in schools of the Preventive Program for teenagers "Personal Dignity. Safety of Life. Civic Position" and methodological resources for its implementation (Osobysta hidnist. Bezpeka Zhyttia. Hromadianska Pozytsia, 2012). However, we again emphasize that only teachers whom pupils trust can successfully "learn how to avoid conflicts, creatively solve problems and find a way out of difficult life situations” (Primakova \& Morska, 2019, p. 70).

It should be noted that for more in-depth analysis of this problem, the generally recognized methods of studying the various components of the educational environment should be used, in particular, space-subject filling, security and comfort of stay of participants of pedagogical interaction, styles of relations between teachers and pupils. Additionally, the process of learning is useful, for example, study of qualities of a person who is characterized by social behaviour, vital values, motives for participating in social activities, etc.

\section{Summary}

The article reveals the essence of child safety (objective and subjective factors) and the components of safe behaviour (hazard prediction, prevention of danger, overcoming danger, creating a safety regime). Outline indicators are outlined that can be used to monitor the safety of the environment and pupils' sense of safety. Based on analysis of other researches, a survey of adolescents and teachers, it is determined that trust in teachers is a prerequisite for child safety, a key factor in ensuring the safety of a teenager at school. Correlation links between respondents' answers show that if there are people in the school who are trusted by the children, then there is a high likelihood of it: there is no abuse and humiliation among pupils, but a favourable emotional atmosphere prevails; pupils jointly solve problems that arise and participate in charitable projects or promotions; there are no physical punishments and humiliation of pupils by teachers, instead the partnership of adults and children is practiced. According to results of the research, conclusions and recommendations concerning tools, ways of establishing trusting relationships between pupils and teachers at school, forming of the social behaviour of adolescents were formulated. 


\section{References}

Balakirieva, O., Bondar, T., Danylenko, H., Levin, Ya., Nhuien, N.-M., Pavlova, D., ... Shevchenko, S. (2019). Sotsialna obumovlenist ta pokaznyky zdorovia pidlitkiv ta molodi: za rezultatamy sotsiolohichnoho doslidzhennia $v$ mezhakh mizhnarodnoho proektu "Zdorovia ta povedinkovi oriientatsii uchnivskoi molodi" [Social conditionality and health indicators of adolescents and youth: According to a sociological survey within the international project "Health and behavioral orientations of student youth"]. Kyiv: Polihrafichnyi tsentr "Foliant".

Bosworth, K., Ford, L., \& Hernandaz, D. (2011). School climate factors contributing to student and faculty perceptions of safety in select Arizona schools. Journal of School Health, 81(4), 194-201.

Bradshaw, C., Waasdorp, T., Debnam, K., \& Lindstrom, J. (2014). Measuring school climate in high schools: A focus on safety, engagement, and the environment. Journal of School Health, 84(9), 593-604.

Fedorchenko, T. (Ed.). (2019). Tekhnolohii formuvannia prosotsialnoi povedinky pidlitkiv urazlyvykh katehorii u zakladakh zahalnoi serednoi osvity [Technologies for shaping the prosocial behavior of vulnerable adolescents in general secondary education]. Kropyvnytskyi: Imeks-LTD.

Hlobalne opytuvannia pro bulinh (znushchannia u shkolakh) [Global survey about bullying (bullying in schools)]. (2016-2017). Retrieved from https://ukraine.ureport.in./v2/ opinion/566

Kyrychenko, V., Yezhova, O., Necherda, V., Tarasova, T., \& Homych, O. (2016). Formuvannia prosotsialnoi povedinky uchniv $v$ umovakh preventyvnoho vykhovnoho seredovyshcha zahalnoosvitnoho navchalnoho zakladu [Formation of prosocial behavior of students in the conditions of the preventive educational environment of a general educational institution]. Ternopil: TzOV “Terno-hraf”.

Naker, D. (2019). Preventing violence against children at schools in resource-poor environments: Operational culture as an overarching entry point. Aggression and Violent Behavior, 47, 268-273.

Noibronner, D. (2018). Ponimat detei. Putevoditel po teorii Gordona Niufelda [Understand the children. Gordon Newfeld theory quide]. Moscow: Izdatelstvo resurs.

Nyufeld, G., \& Mate, G. (2018). Ne upuskaite svoih detei [Do not miss your children]. Moscow: Izdatelstvo resurs.

Osobysta hidnist. Bezpeka zhyttia. Hromadianska pozytsia. (2012). Prohrama vychovnoi roboty z uchniamy z pytan protydii torhivli liudmy; I.D. Zvierieva, Zh.V. Petrochko (Eds.), Kyiv: TOV “Osnova”.

Primakova, V., \& Morska, L. (2019). Educating Students in a Safe Educational Environment in Secondary Schools of Ukraine: Current Issues and Challenges. Pedagogical Contexts, 1(12), 63-71.

Shkilnyi bullinh: UNICEF nadav novi dani U-Report pro kiberbulinh i bulinh $v$ osvitnomu seredovyshchi [School bulling: UNICEF provides new U-Report data on cyberbullying and bullying in education]. (2019). Retrieved from http://knowledge.org.ua/uk/shkilnijbulling-junisef-nadav-novi-dani-u-report-pro-kiberbuling-i-buling-v-osvitnomuseredovishhi/

White, J. (2019). Addressing school violence and bullying: Evidence briefing. Edinburgh: NHS Health Scotland. 
Petrochko \& Kyrychenko, 2020. Pupils’ Trust in Teachers as a Key Prerequisite for Child Safety in School

Yezhova, O., Kyrychenko, V., Tarasova, T., Fedorchenko, T., Muromets, V., \& Necherda, B. (2014). Formuvannia preventyvnoho vykhovnoho seredovyshcha zahalnoosvitnoho navchalnoho zakladu [Formation of preventive educational environment of a comprehensive educational institution]. Kirovohrad: Imeks LTD.

Zakon Ukrainy "Pro osvitu" [The Law of Ukraine "On Education"] (No.2145-VIII, September 05). (2017). Retrieved from https://zakon.rada.gov.ua/laws/show/2145-19

Zakon Ukrainy "Pro vnesennia zmin do deiakykh zakonodavchykh aktiv Ukrainy shchodo protydii bulinhu (tskuvanniu)" [The Law of Ukraine "On Amendments to Some Legislative Acts of Ukraine on Countering Bullying”] (No.2657-VIII, December 18). (2018). Retrieved from https://zakon.rada.gov.ua/laws/show/2657-19

Zauvazhennia zahalnoho poriadku № 20 pro realizatsiiu prav dytyny v pidlitkovomu vitsi [General Comment No. 20 on the Rights of the Child in Adolescence]. (2016). Retrieved from https://www.msp.gov.ua/timeline/Konvenciya-OON-z-prav-ditini.html 